\title{
Innovative Surgical System for Breast Cancer Based on Real-time Excising of Hypoxic Lesions Significantly Reduced the Positive Cavity Side Margin
}

Research

Keywords:

Posted Date: January 26th, 2021

DOI: https://doi.org/10.21203/rs.3.rs-100298/v2

License: (1) This work is licensed under a Creative Commons Attribution 4.0 International License. Read Full License 


\section{Abstract}

The authors have requested that this preprint be withdrawn due to erroneous posting.

\section{Full Text}

The authors have withdrawn this preprint from Research Square. 